\title{
Chronic Pulmonary Toxicity Study of Indium-Tin Oxide and Indium Oxide Following Intratracheal Instillations into the Lungs of Hamsters
}

\author{
Akiyo Tanaka ${ }^{1}$, Miyuki Hirata ${ }^{1}$, Toshiaki Homma ${ }^{2}$ and Yutaka KiYohara ${ }^{1}$ \\ ${ }^{1}$ Department of Environmental Medicine, Graduate School of Medical Sciences, Kyushu University and ${ }^{2}$ Division \\ of Respiratory Disease, Teikyo University Chiba Medical Center, Japan
}

\begin{abstract}
Chronic Pulmonary Toxicity Study of Indium-Tin Oxide and Indium Oxide Following Intratracheal Instillations into the Lungs of Hamsters: Akiyo TANAKA, et al. Department of Environmental Medicine, Graduate School of Medical Sciences, Kyushu University-Objectives: The aim of this study was to clarify the chronic toxicological effects of indium-tin oxide (ITO) and indium oxide $\left(\ln _{2} \mathrm{O}_{3}\right)$ on laboratory animals. Methods: Male Syrian golden hamsters were intratracheally administered $3 \mathrm{mg} / \mathrm{kg}$ or $6 \mathrm{mg} / \mathrm{kg}$ of ITO particles, or $2.7 \mathrm{mg} / \mathrm{kg}$ or $5.4 \mathrm{mg} / \mathrm{kg}$ of $\ln _{2} \mathrm{O}_{3}$ particles, containing $2.2 \mathrm{mg} / \mathrm{kg}$ or $4.5 \mathrm{mg} / \mathrm{kg}$ of indium, twice a week, for 8 wk. Control hamsters were given vehicle of distilled water only. The hamsters were euthanized serially up to 78 wk after the final instillation and the toxicological effects were determined. Results: Body weight gain was significantly suppressed in the ITO $6 \mathrm{mg} / \mathrm{kg}$-treated hamsters compared with the control group, but not in the ITO $3 \mathrm{mg} / \mathrm{kg}$-treated or $\ln _{2} \mathrm{O}_{3}$-treated hamsters. Relative lung weights among all the indium-treated groups were significantly increased compared to that in the control group throughout the observation period. The serum indium concentration among all the indiumtreated groups gradually increased up to the end of the observation period. Histopathologically, foci of slight to severe pulmonary inflammatory response with diffuse alveolar or bronchiolar cell hyperplasia, expansion of the alveolar spaces and interstitial fibrotic proliferation were present in all the indium-treated hamsters and the severity of these lesions worsened with the passage of time. Lung benign adenomas were only manifest in
\end{abstract}

Received Jul 1, 2009; Accepted Oct 6, 2009 Published online in J-STAGE Nov 25, 2009

Correspondence to: A. Tanaka, Department of Environmental Medicine, Graduate School of Medical Sciences, Kyushu University, Venture Business Laboratory 2F, 6-10-1 Hakozaki, Higashi-ku, Fukuoka 812-8581, Japan

(e-mail:atanaka@envmed.med.kyushu-u.ac.jp)
3 out of 15 of the ITO $6 \mathrm{mg} / \mathrm{kg}$-treated hamsters. Conclusions: The present results clearly demonstrate that ITO and $\ln _{2} \mathrm{O}_{3}$ particles caused chronic pulmonary toxicity when repeated intratracheal instillations were given to hamsters.

(J Occup Health 2010; 52: 14-22)

Key words: Chronic pulmonary toxicity, Hamsters, Indium oxide, Indium-tin oxide

Indium-tin oxide (ITO), which is a sintered alloy containing $90 \%$ indium oxide and $10 \%$ tin oxide, is used for liquid-crystal displays (LCDs) or plasma displays and mobile phone displays. In 2007, the indium demand for ITO is said to have accounted for $90 \%$ of the total indium demand in Japan and ITO production is expected to rise significantly due to its increasing use in electronic devices, such as LCDs ${ }^{1}$. Due to the increasing production of ITO, the potential health hazards of occupational or environmental exposure to this material have began to cause great concern. Since the mid 1990's, data have become available indicating that indium compounds can be toxic to animals ${ }^{2-12)}$, although there is little information regarding the adverse health effects for workers exposed to indium compounds. In 2003, the first case of interstitial pneumonia caused by occupational exposure to ITO was reported $^{13)}$. Interstitial pneumonia and numerous fine ITO particles were recognized in the lung of a worker who was engaged in the metal-processing industry as an operator of a wet surface grinder dealing with ITO sputtering targets. An extremely high indium concentration $(290 \mu \mathrm{g} / l)$ was detected in the worker's serum. However, the question as to whether or not exposure to indium, including ITO, is a potential occupational health hazard for employees handling these materials has not been fully resolved.

In our previous study, which has been the only study dealing with the subchronic toxicity of ITO, we 
demonstrated the pulmonary toxicity of $6 \mathrm{mg} / \mathrm{kg}$ of ITO (4.5 mg In/ $/ \mathrm{kg}$ ) and $6 \mathrm{mg} / \mathrm{kg}$ of indium phosphide (InP, $4.8 \mathrm{mg} \mathrm{In} / \mathrm{kg}$ ) per one instillation, when given to hamsters in repeated intratracheal instillations over a 4 mo period $^{11)}$. Significant depression of body-weight gain was observed in the InP-treated hamsters compared with the controls, but not in the ITO-treated hamsters. Concerning lung lesions, both pneumonia and hyperplastic lesions with squamous cell metaplasia were observed in the InP group. Pneumonia was recognized in the ITO group, but hyperplastic lesions were not. Both ITO and InP particles are toxic to the lung of hamsters, and InP has greater systemic or pulmonary toxic effects than ITO. Accordingly, we considered that indium was the main cause of the lung lesions.

In this study, we evaluated the chronic pulmonary toxic effect of ITO when administered to the trachea of hamsters twice a week for $8 \mathrm{wk}$ according to the method of Yamazaki et al. ${ }^{9)}$, who demonstrated the chronic pulmonary toxicity of indium arsenide (InAs) and InP which are semiconductor materials containing indium. ITO was administered at a dose of $6 \mathrm{mg} / \mathrm{kg}$ or $3 \mathrm{mg} / \mathrm{kg}$, the same and half the dose used in our previous study ${ }^{11)}$. Indium oxide, which is the main material of ITO, was also used in order to compare the toxicity of indium compounds, and it was administered in equimolar amounts of indium to those of ITO.

\section{Materials and Methods}

\section{Test materials}

ITO particles were donated by a company. They contained $74.4 \%$ (wt \%) indium and $7.8 \%$ tin, the remainder being oxygen. Indium oxide, over $99.99 \%$ pure, was purchased from Katayama Chemicals, Osaka, Japan. The mean particle diameter for ITO was $0.95 \mu \mathrm{m}$ [og (geometric standard deviation): 2.42], as measured by an image analyzer (Nikon Co. Ltd, Tokyo Japan) using scanning electron microscopy (T-220, JEOL Ltd, Tokyo, Japan). The mean particle diameter for indium oxide was $0.14 \mu \mathrm{m}$, which was found from the ratio of the surface area of the particle by the BET adsorption method. ITO particles were analyzed in an energy dispersive Xray fluorescence element analyzer (MESA-500, Horiba Ltd., Kyoto, Japan). The ITO particles contained $0.16 \%$ zirconium and $0.02 \%$ silicon. ITO and indium oxide particles were suspended in sterile distilled water just prior to each instillation.

\section{Animals}

One hundred sixty-six male Syrian golden hamsters, from the colony of Japan SLC Inc. (Shizuoka, Japan) were purchased at $6 \mathrm{wk}$ of age and housed under temperature conditions of between $22^{\circ} \mathrm{C}$ and $25^{\circ} \mathrm{C}$. All the animals were maintained under a cycle of $12-\mathrm{h}$ lighting, within a specific pathogen-free laboratory room at the Laboratory of Animal Experiments, Graduate School of Medical Sciences, Kyushu University. Five hamsters were housed in one stainless steel cage and provided with a commercial diet (CE-2 pellets, Clea Japan Inc., Tokyo, Japan) and tap water ad libitum. The intratracheal instillations were started on 8 -wk-old hamsters after an acclimatization period of $2 \mathrm{wk}$.

\section{Intratracheal instillation of materials}

The hamsters, mean \pm SD weight of $112.2 \pm 6.9 \mathrm{~g}$, were randomly divided into 5 groups: the control group $(\mathrm{n}=40)$, those treated by a dose of $3 \mathrm{mg} / \mathrm{kg}$ of ITO (ITO 3 $\mathrm{mg}$ group, $\mathrm{n}=40$ ), $6 \mathrm{mg} / \mathrm{kg}$ of ITO (ITO $6 \mathrm{mg}$ group, $\mathrm{n}=40), 2.7 \mathrm{mg} / \mathrm{kg}$ of $\operatorname{In}_{2} \mathrm{O}_{3}\left(\operatorname{In}_{2} \mathrm{O}_{3} 2.7 \mathrm{mg}\right.$ group, $\left.\mathrm{n}=23\right)$, and $5.4 \mathrm{mg} / \mathrm{kg}$ of $\operatorname{In}_{2} \mathrm{O}_{3}\left(\mathrm{In}_{2} \mathrm{O}_{3} 5.4 \mathrm{mg}\right.$ group, $\left.\mathrm{n}=23\right)$. There was no significant difference in body weight among the groups at the start of the experiment. ITO and indium oxide were suspended in sterile distilled water just prior to each instillation. Each material was instilled into the trachea of hamsters which had been anesthetized with ether, twice a week, a total of 16 times, during an 8-wk period. Each instillation per animal comprised $3 \mathrm{mg} / \mathrm{kg}$ or $6 \mathrm{mg} / \mathrm{kg}$ ITO (2.2 mg In/ $\mathrm{kg}$ or $4.5 \mathrm{mg} \mathrm{In} / \mathrm{kg})$ or 2.7 $\mathrm{mg} / \mathrm{kg}$ or $5.4 \mathrm{mg} / \mathrm{kg}$ as $\mathrm{In}_{2} \mathrm{O}_{3}(2.2 \mathrm{mg} \mathrm{In} / \mathrm{kg}$ or $4.5 \mathrm{mg} \mathrm{In} /$ $\mathrm{kg}$ ), these doses being either the same as, or half the quantity of the molar indium dose used in our earlier study $^{11)}$. The control hamsters received $1.0 \mathrm{ml} / \mathrm{kg}$ of distilled water only. Six to eight surviving hamsters in each group were euthanized by carbon dioxide gas 0,8 , 16,40 or $78 \mathrm{wk}$ after the final instillation in the two ITO groups and the control group, and 0, 16 or 40 wk after the final instillation in the two $\operatorname{In}_{2} \mathrm{O}_{3}$ groups, and then autopsied. The blood was taken from the posterior vena cava and the serum was separated after centrifugation. Resected lungs were weighed and fixed in $10 \%$ neutral buffered formalin and processed in paraffin. Specimens were cut at a thickness of $6 \mu \mathrm{m}$ and each section was stained with hematoxylin-eosin. These sections were examined by light microscopy. Histopathological findings in the lung were scored as present or absent; if they were absent, findings were expressed as negative. In the case of pulmonary lesions, the severity of each of the lung lesions was graded on a 4-item scale of slight to severe, indicating the approximate fraction of the lung or structure judged to be involved (slight $=1-10 \%$, mild $=11-24 \%$, moderate $=25-50 \%$, and severe $=51-$ $100 \%)$.

Quantifying of serum indium concentration by inductively coupled plasma mass spectrometry (ICP-MS)

Serum samples were stored at $-80^{\circ} \mathrm{C}$ until analysis. For pretreatment, $1 \mathrm{~m} l$ of serum was digested with $5 \mathrm{ml}$ of $68 \%$ ultra-pure nitric acid (TAMAPURE-AA-100, Tama Chemicals Co., Japan) and $0.5 \mathrm{ml}$ of $35 \%$ ultrapure hydrogen peroxide (TAMAPURE-A-A-100) in a 
microwave digestion apparatus (Multiwave 3000, PerkinElmer, Japan). The digested samples were diluted to 20 $\mathrm{m} l$ with ultra-pure water and injected into the ICP-MS (Agilent 7500c, Yokogawa Analytical Systems, Japan) at the Center of Advanced Instrumental Analysis, Kyushu University. Rhodium was used as an internal standard for the indium measurement. The detection limit of serum indium was $0.1 \mu \mathrm{g} / \mathrm{l}$. If serum indium was below the detection limit, $0.05 \mu \mathrm{g} / l$ was used in the statistical analysis.

Data on body weight were analyzed by two-way repeated measure ANOVA. Fischer's least significant difference procedure was used in the case of organ weight after one-way analysis of variance. In all the statistical comparisons, a $p$ value of less than 0.05 was used to determine significant differences. Fischer's exact probability test was used for the pulmonary tumor incidence rate.

These experiments were conducted according to the Guidelines for Animal Experiments in the Graduate School of Medical Sciences, Kyushu University and under the Law (No. 105) and Notification (No. 6) of the Government of Japan.

\section{Results}

The mean total dosage received per animal (mean \pm S.D.) was $6.4 \pm 0.5 \mathrm{mg}(4.8 \pm 0.4 \mathrm{mg}$ as In $)$ of ITO particles in the ITO $3 \mathrm{mg}$ group, $12.7 \pm 1.2 \mathrm{mg}(9.5 \pm 0.9$ $\mathrm{mg}$ as In) of ITO particles in the ITO $6 \mathrm{mg}$ group, $5.8 \pm$ $0.4 \mathrm{mg}(4.8 \pm 0.3 \mathrm{mg}$ as $\mathrm{In})$ of $\mathrm{In}_{2} \mathrm{O}_{3}$ particles in the $\mathrm{In}_{2} \mathrm{O}_{3}$ $2.7 \mathrm{mg}$ group and $11.5 \pm 0.7 \mathrm{mg}(9.5 \pm 0.6 \mathrm{mg}$ as $\mathrm{In})$ of $\mathrm{In}_{2} \mathrm{O}_{3}$ particles in the $\operatorname{In}_{2} \mathrm{O}_{3} 5.4 \mathrm{mg}$ group. No hamsters died during the instillation period and any animals which died during the observation period were excluded from the evaluation. Among the control animals, 2 were cannibalized and 1 died of emaciation. In the ITO $3 \mathrm{mg}$ group, 1 was cannibalized and 2 died of emaciation. In the ITO $6 \mathrm{mg}$ group, 2 died of emaciation. Thirty-seven animals in the control group, 37 in the ITO $3 \mathrm{mg}$ group, 38 in the ITO $6 \mathrm{mg}$ group, 23 in the $\mathrm{In}_{2} \mathrm{O}_{3} 2.7 \mathrm{mg}$ group, and 23 in the $\mathrm{In}_{2} \mathrm{O}_{3} 5.4 \mathrm{mg}$ group were examined, as scheduled. At least 6 hamsters in each group were examined at each sacrifice time during the observation period.

Intratracheal instillations of ITO or $\operatorname{In}_{2} \mathrm{O}_{3}$ did not lead to any suppression of body weight gain during instillation period. Changes in body weight among the two ITO groups throughout the observation period are shown in Fig. 1 for the 19 animals (6 in ITO $3 \mathrm{mg}$ group, 7 in ITO $6 \mathrm{mg}$ group, 6 in control group) observed until $78 \mathrm{wk}$ after the final instillation. Mean body weight (mean \pm S.D.) at $78 \mathrm{wk}$ was $149.8 \pm 10.9 \mathrm{~g}$ in the ITO $3 \mathrm{mg}$ group, $130.2 \pm 13.9 \mathrm{~g}$ in the ITO $6 \mathrm{mg}$ group and $138.0 \pm 22.2 \mathrm{~g}$ in the control group. The body weight of the two ITO groups and the control group gradually decreased from

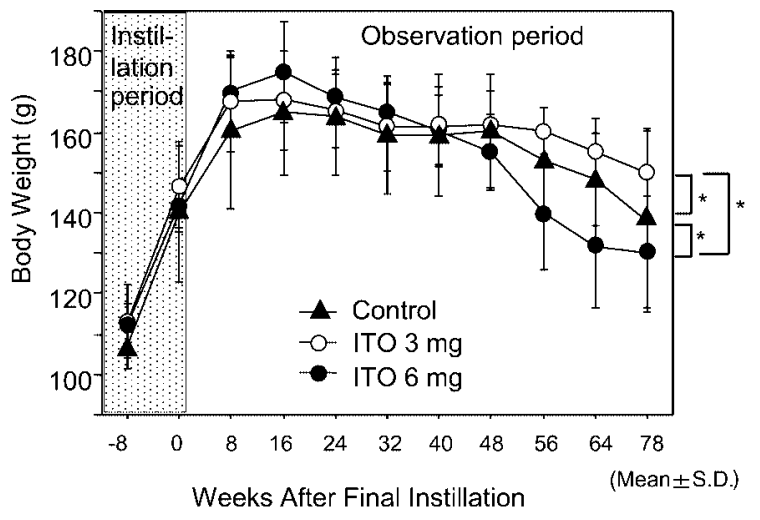

Fig. 1. Changes in body weight gain among the two ITO groups during the instillation and observation periods. The results shown are mean \pm S.D. of hamsters euthanized at $78 \mathrm{wk}$. Statistical significance was determined by two-way repeated measure ANOVA. Significant differences are indicated by $*(p<0.05)$.

$40 \mathrm{wk}$ after the final instillation. The trend in body weight change of the ITO $6 \mathrm{mg}$ group was significantly below $(p<0.05)$ that of the ITO $3 \mathrm{mg}$ group and the control group, while that of the ITO $3 \mathrm{mg}$ group was significantly above that of the control group between $40 \mathrm{wk}$ and $78 \mathrm{wk}$ after the final instillation. Concerning the trend in body weight change in the two $\operatorname{In}_{2} \mathrm{O}_{3}$ groups, throughout the observation period, there were no significant differences between the two $\mathrm{In}_{2} \mathrm{O}_{3}$ groups and the control group for the 23 animals ( 8 in $\operatorname{In}_{2} \mathrm{O}_{3} 2.7 \mathrm{mg}$ group, 8 in $\operatorname{In}_{2} \mathrm{O}_{3} 5.4$ mg group, 7 in control group) observed until $40 \mathrm{wk}$ after the final instillation. Mean body weight (mean \pm S.D.) at $40 \mathrm{wk}$ was $159.8 \pm 8.9 \mathrm{~g}$ in the $\mathrm{In}_{2} \mathrm{O}_{3} 2.7 \mathrm{mg}$ group, $161.4 \pm 7.4 \mathrm{~g}$ in the $\operatorname{In}_{2} \mathrm{O}_{3} 5.4 \mathrm{mg}$ group and $166.0 \pm 16.2$ $\mathrm{g}$ in the control group. No systemic signs such as respiratory distress, dermatological abnormality, or behavioral or neurological disorder appeared during the observation period in any of the groups.

Changes in the relative lung weight during the observation period are shown in Fig. 2. The relative lung weights in the two ITO and the two $\operatorname{In}_{2} \mathrm{O}_{3}$ groups were significantly higher than that in the control group at each time point. Moreover, the ITO $6 \mathrm{mg}$ group demonstrated higher lung weight than the ITO $3 \mathrm{mg}$ group at each time point, while the $\mathrm{In}_{2} \mathrm{O}_{3} 5.4 \mathrm{mg}$ group demonstrated higher lung weights than the $\operatorname{In}_{2} \mathrm{O}_{3} 2.7 \mathrm{mg}$ group at 16 and 40 wk following the final instillation, the differences being significant. The relative lung weights of the ITO $3 \mathrm{mg}$ and $6 \mathrm{mg}$ groups were significantly higher than those of the $\mathrm{In}_{2} \mathrm{O}_{3} 2.7 \mathrm{mg}$ group at $16 \mathrm{wk}$ and $40 \mathrm{wk}$ and that of the $\mathrm{In}_{2} \mathrm{O}_{3} 5.4 \mathrm{mg}$ group at week 0 . The increase in relative lung weight in each of the indium groups rose dosedependently until the end of the observation period.

The serum indium concentrations during the observation 


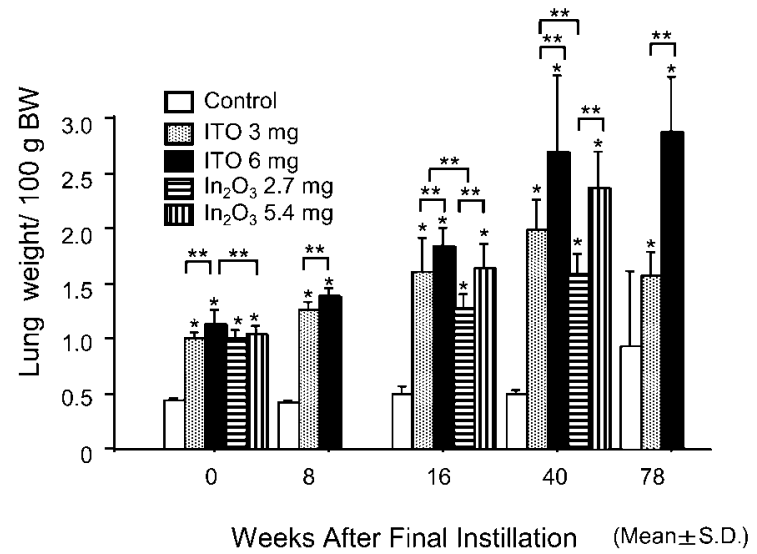

Fig. 2. Changes in relative lung weight from the final instillation. The results shown are mean \pm S.D. of relative lung weights of hamsters euthanized at each time point. Statistical significance was determined by Fischer's least significant difference procedure after one-way analysis of variance. *: Significantly different from the control group $(p<0.05)$. **: Significantly different in each group $(p<0.05)$.

period, except those of week 0 , of the two ITO and the two $\mathrm{In}_{2} \mathrm{O}_{3}$ groups are shown in Fig. 3. The serum samples of all groups at week 0 were lost in an accident. The serum indium concentration gradually increased from $8 \mathrm{wk}$ to 78 wk in the two ITO groups, and from 16 to $40 \mathrm{wk}$ in the two $\mathrm{In}_{2} \mathrm{O}_{3}$ groups following the final instillation. At the end of the observation period, serum indium levels were $237.4 \pm$ $127.0 \mu \mathrm{g} / \mathrm{l}$ in the ITO $3 \mathrm{mg}$ group and $436.2 \pm 149.3 \mu \mathrm{g} / \mathrm{l}$ in the ITO $6 \mathrm{mg}$ group at $78 \mathrm{wk}$, and $144.3 \pm 46.2 \mu \mathrm{g} / \mathrm{l}$ in the $\mathrm{In}_{2} \mathrm{O}_{3} 2.7 \mathrm{mg}$ group and $230.2 \pm 23.3 \mu \mathrm{g} / \mathrm{l}$ in the $\mathrm{In}_{2} \mathrm{O}_{3}$ $5.4 \mathrm{mg}$ group at $40 \mathrm{wk}$. The differences in indium serum levels between the two doses of each material were significant. The differences in serum indium levels between the two ITO groups at 8, 16, $40 \mathrm{wk}$ and between the two $\operatorname{In}_{2} \mathrm{O}_{3}$ group at $16 \mathrm{wk}$ following the final instillation were not significant. Furthermore, between the ITO groups and the $\mathrm{In}_{2} \mathrm{O}_{3}$ groups administered an equimolar amount of indium (ITO $3 \mathrm{mg}$ group vs $\mathrm{In}_{2} \mathrm{O}_{3} 2.7 \mathrm{mg}$ group, ITO 6 $\mathrm{mg}$ group vs $\mathrm{In}_{2} \mathrm{O}_{3} 5.4 \mathrm{mg}$ group), differences in serum indium level were not significant at 16 and $40 \mathrm{wk}$. Indium was not detected in the serum of the control group at each time point.

The severity of pathologic change in the lungs is shown in Table 1. Pulmonary pathological change in the two ITO and the two $\operatorname{In}_{2} \mathrm{O}_{3}$ groups was almost the same morphologically, except for granulomas, and the changes were gradual. Diffuse foci of slight to severe inflammation were present in the two ITO groups and the two $\operatorname{In}_{2} \mathrm{O}_{3}$ groups during the observation period. Although slight inflammatory lesions appeared at an early stage $(0,8,16 \mathrm{wk})$ in the indium-treated groups, the

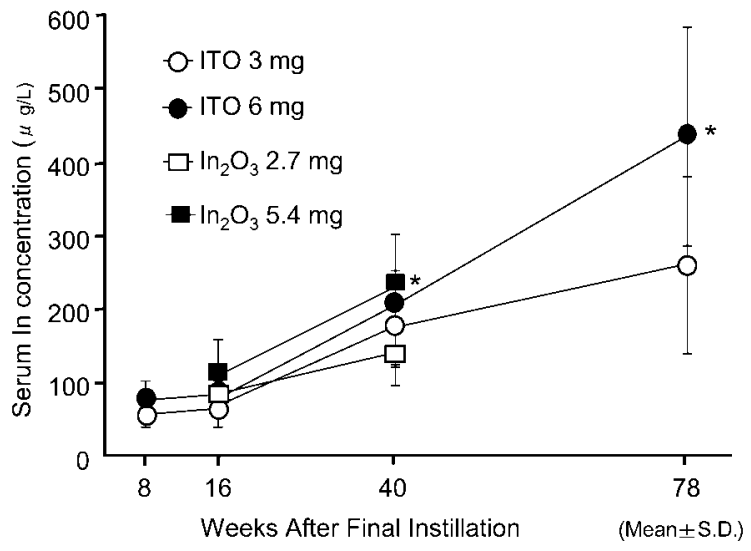

Fig. 3. Changes in serum indium concentration from the final instillation. The results shown are mean \pm S.D. of serum indium concentration of hamsters euthanized at each time point. Statistical significance was determined by Fischer's least significant difference procedure after one-way analysis of variance. *: Significantly different from the control group $(p<0.05)$.

degree of inflammation was greatly increased at the late stage (40, $78 \mathrm{wk})$. Within the region of the inflammatory foci, alveolar septa diffusely lined with hyperplastic alveolar epithelium or regenerative epithelium with mild cellular atypia, and infiltration of inflammatory cells to the alveolar spaces or bronchiolar lumen were seen. The inflammatory cells mostly consisted of neutrophils mixed with alveolar macrophages, and mononuclear cells, which were observed within the alveolar spaces, or bronchiolar lumen. Moreover, alveolar macrophages with an expanded cytoplasm or including ITO or $\mathrm{In}_{2} \mathrm{O}_{3}$ particles were seen within the alveolar spaces. Multinuclear largesized alveolar macrophages were only observed in the two ITO groups at $78 \mathrm{wk}$, but not in either of the $\operatorname{In}_{2} \mathrm{O}_{3}$ groups until $40 \mathrm{wk}$ following the final instillation. Exudation including necrotic cell debris was seen within the alveolar spaces at a degree of mild to moderate throughout the observation period, in all the indiumtreated groups. Cholesterol clefts gradually became manifest within the alveolar spaces after $16 \mathrm{wk}$ in all the indium-treated groups. From 0 to $40 \mathrm{wk}$, granulomas were manifest in the two $\operatorname{In}_{2} \mathrm{O}_{3}$ groups, and almost all the granulomas consisted of coagulation of $\operatorname{In}_{2} \mathrm{O}_{3}$ particles at their center. The degree of granuloma formation was gradually reduced at $40 \mathrm{wk}$. Slight foci of granulomas were seen temporarily at $16 \mathrm{wk}$ in the two ITO groups. Appearance of expansion of the alveolar spaces was clearly visible in all the indium-treated groups at the late stage (40 and $78 \mathrm{wk}$ ). This lesion gradually worsened, and was especially more marked in the ITO $6 \mathrm{mg}$ and the $\mathrm{In}_{2} \mathrm{O}_{3} 5.4 \mathrm{mg}$ groups, compared with the lower dose 
Table 1. Pathological changes in the hamster lung after intratracheal instillation of ITO or $\operatorname{In}_{2} \mathrm{O}_{3}$

\begin{tabular}{|c|c|c|c|c|c|c|}
\hline \multirow[t]{2}{*}{ Pathological changes } & \multirow[t]{2}{*}{ Group } & \multicolumn{5}{|c|}{ Wk after final instillation (wk) } \\
\hline & & 0 & 8 & 16 & 40 & 78 \\
\hline \multirow{4}{*}{$\begin{array}{l}\text { Inflammatory response } \\
\text { with diffuse hyperplasia of } \\
\text { bronchiolo-alveolar } \\
\text { epithelium }\end{array}$} & ITO $3 \mathrm{mg}$ & + & \pm & \pm & + & $3+$ \\
\hline & ITO 6 mg & + & \pm & \pm & + & $3+$ \\
\hline & $\mathrm{In}_{2} \mathrm{O}_{3} 2.7 \mathrm{mg}$ & \pm & ND & \pm & + & ND \\
\hline & $\mathrm{In}_{2} \mathrm{O}_{3} 5.4 \mathrm{mg}$ & \pm & ND & \pm & + & ND \\
\hline \multirow[t]{4}{*}{ Exudation } & ITO $3 \mathrm{mg}$ & + & + & $2+$ & + & + \\
\hline & ITO $6 \mathrm{mg}$ & $2+$ & $2+$ & + & + & + \\
\hline & $\mathrm{In}_{2} \mathrm{O}_{3} 2.7 \mathrm{mg}$ & + & ND & + & + & ND \\
\hline & $\mathrm{In}_{2} \mathrm{O}_{3} 5.4 \mathrm{mg}$ & + & ND & + & + & ND \\
\hline \multirow[t]{4}{*}{ Cholesterol Clefts } & ITO $3 \mathrm{mg}$ & - & - & \pm & + & $2+$ \\
\hline & ITO 6 mg & - & - & \pm & \pm & $2+$ \\
\hline & $\mathrm{In}_{2} \mathrm{O}_{3} 2.7 \mathrm{mg}$ & - & ND & \pm & + & ND \\
\hline & $\mathrm{In}_{2} \mathrm{O}_{3} 5.4 \mathrm{mg}$ & - & ND & \pm & \pm & ND \\
\hline \multirow[t]{4}{*}{ Granuloma } & ITO $3 \mathrm{mg}$ & - & - & \pm & - & - \\
\hline & ITO 6 mg & - & - & \pm & - & - \\
\hline & $\mathrm{In}_{2} \mathrm{O}_{3} 2.7 \mathrm{mg}$ & + & ND & $2+$ & + & ND \\
\hline & $\mathrm{In}_{2} \mathrm{O}_{3} 5.4 \mathrm{mg}$ & + & ND & $2+$ & + & ND \\
\hline \multirow[t]{4}{*}{ Expansion of alveolar spaces } & ITO $3 \mathrm{mg}$ & - & \pm & \pm & + & \pm \\
\hline & ITO $6 \mathrm{mg}$ & \pm & \pm & \pm & + & $2+$ \\
\hline & $\mathrm{In}_{2} \mathrm{O}_{3} 2.7 \mathrm{mg}$ & - & ND & \pm & + & ND \\
\hline & $\mathrm{In}_{2} \mathrm{O}_{3} 5.4 \mathrm{mg}$ & \pm & ND & \pm & $2+$ & ND \\
\hline \multirow{4}{*}{$\begin{array}{l}\text { Interstitial fibrotic } \\
\text { proliferation }\end{array}$} & ITO $3 \mathrm{mg}$ & - & - & - & \pm & \pm \\
\hline & ITO 6 mg & \pm & \pm & - & \pm & \pm \\
\hline & $\mathrm{In}_{2} \mathrm{O}_{3} 2.7 \mathrm{mg}$ & - & ND & - & \pm & ND \\
\hline & $\mathrm{In}_{2} \mathrm{O}_{3} 5.4 \mathrm{mg}$ & - & ND & \pm & + & ND \\
\hline \multirow{4}{*}{$\begin{array}{l}\text { Bronchiolo-alveolar } \\
\text { cell hyperplasia }\end{array}$} & ITO $3 \mathrm{mg}$ & \pm & \pm & \pm & \pm & + \\
\hline & ITO $6 \mathrm{mg}$ & \pm & \pm & \pm & \pm & $2+$ \\
\hline & $\mathrm{In}_{2} \mathrm{O}_{3} 2.7 \mathrm{mg}$ & \pm & ND & \pm & \pm & ND \\
\hline & $\mathrm{In}_{2} \mathrm{O}_{3} 5.4 \mathrm{mg}$ & \pm & ND & \pm & \pm & ND \\
\hline
\end{tabular}

The severity of the lung lesions was categorized by five grades. -: negative; \pm : slight; +: mild; $2+$ : moderate; $3+$ : severe. ND: Not determined.

groups. Slight interstitial fibrotic proliferation appeared gradually after $40 \mathrm{wk}$ in both the ITO $3 \mathrm{mg}$ group and $\mathrm{In}_{2} \mathrm{O}_{3} 2.7 \mathrm{mg}$ group. While it was seen from 0 to $78 \mathrm{wk}$ in the ITO $6 \mathrm{mg}$ group, and from 16 to $40 \mathrm{wk}$ in the $\mathrm{In}_{2} \mathrm{O}_{3}$ $5.4 \mathrm{mg}$ group. Slight foci of alveolar or bronchiolar cell hyperplasia were seen in all the ITO or $\mathrm{In}_{2} \mathrm{O}_{3}$ groups from 0 to $40 \mathrm{wk}$. After $40 \mathrm{wk}$, the degree of hyperplasia progressed in the two ITO groups, becoming more severe in the ITO $6 \mathrm{mg}$ group compared with the ITO $3 \mathrm{mg}$ group. Most of individual ITO or $\operatorname{In}_{2} \mathrm{O}_{3}$ particles or aggregates of those particles were present in the cytoplasm of alveolar macrophages, and a few of those particles were seen in the alveolar spaces, interstitial tissue, and in the lymphoid tissue around bronchioles in the lung. Those particles were continuously present in the lung up to the end of the observation period (Fig. 4). Neither inflammatory response, interstitial fibrosis nor hyperplastic lesion was evident in the control group.

The incidence of benign pulmonary tumor or localized proliferating lesions is shown in Table 2. Benign bronchiolo-alveolar adenoma was only seen in the ITO 6 $\mathrm{mg}$ group (in 1 out of 8 hamsters at $40 \mathrm{wk}$, and 2 out of 7 hamsters at $78 \mathrm{wk}$ ), and consisted of uniform, one or two layers of columnar or cuboidal cells with no mitotic figures. The incidence rate of lung adenoma was $20 \%$ in the ITO $6 \mathrm{mg}$ group. No malignant tumors in the lung were observed in any of the experimental groups, and there was no significant difference in lung adenoma incidence between the ITO $6 \mathrm{mg}$ group and the control group. Besides the appearance of lung adenomas, 

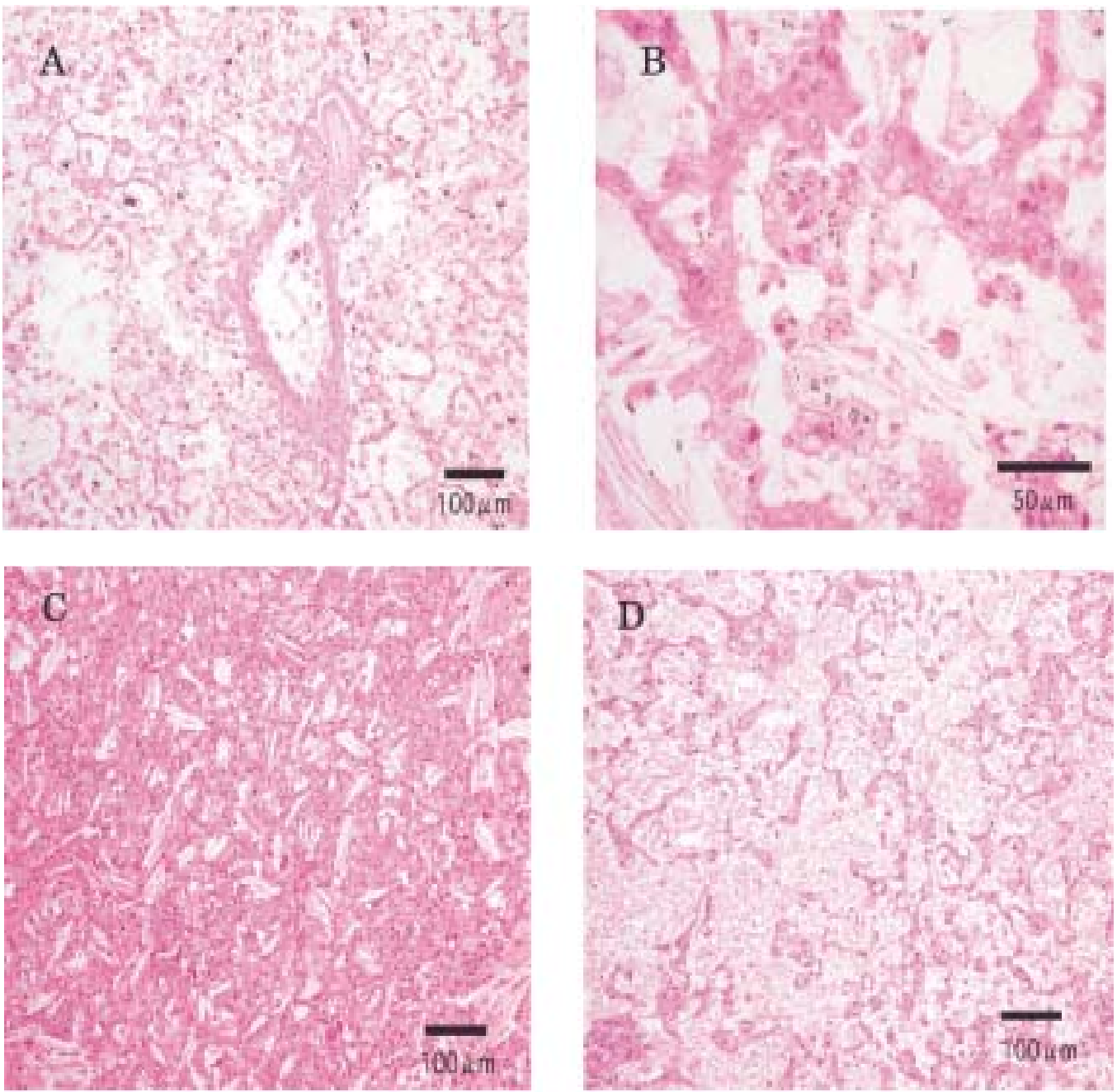

Fig. 4. Photomicrograph of the lung showing inflammatory change. (A) A hamster in the ITO 6 mg group at 78 wk. Inflammation and alveolar cell hyperplasia, alveolar macrophage infiltration to the alveolar spaces and bronchiolar lumen, and exudation in the alveolar spaces are evident. (B) A hamster in the ITO $6 \mathrm{mg}$ group at $78 \mathrm{wk}$. An alveolar macrophage showing expanded cytoplasm containing ITO particles is apparent. (C) A hamster in the $\operatorname{In}_{2} \mathrm{O}_{3} 2.7 \mathrm{mg}$ group at 40 wk. Numerous cholesterol clefts in the alveolar spaces are evident. (D) A hamster in the $\mathrm{In}_{2} \mathrm{O}_{3} 5.4 \mathrm{mg}$ group at $40 \mathrm{wk}$. Expansion of the alveolar spaces can be seen, with exudation filling them.
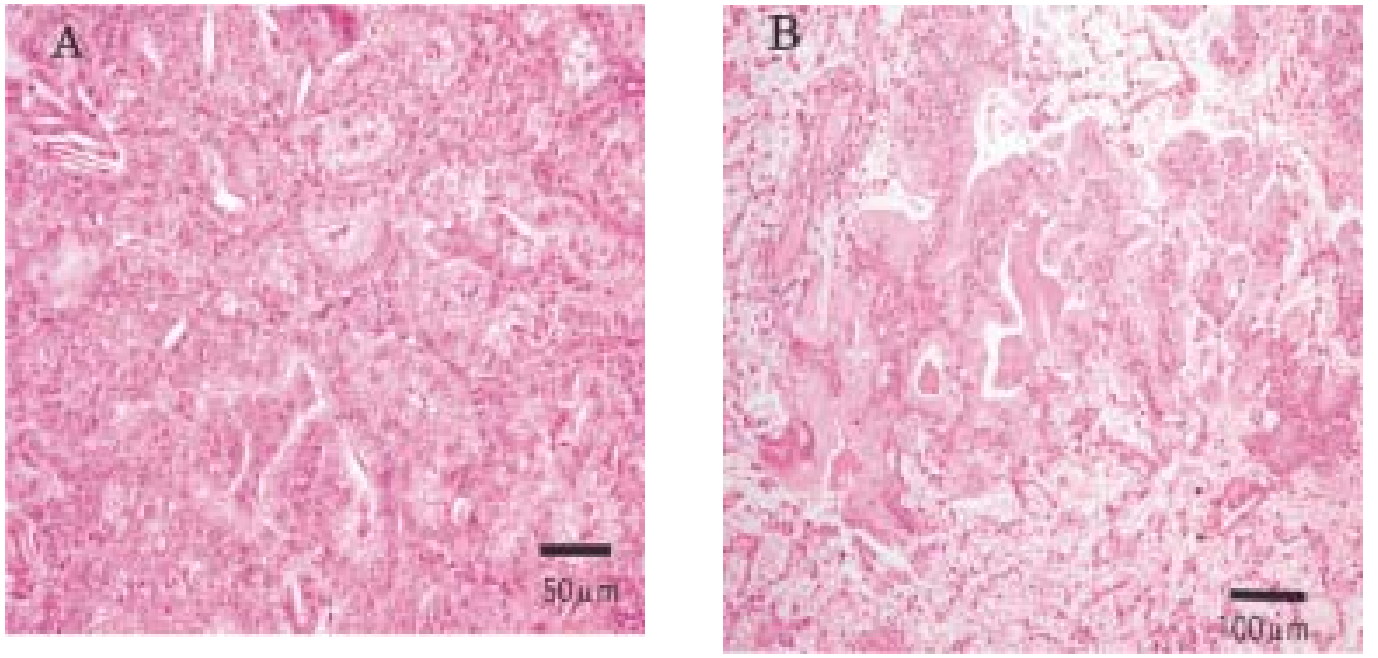

Fig. 5. Photomicrograph of the lung. (A) Pulmonary adenoma in a hamster in the ITO $6 \mathrm{mg}$ group at 78 wk. Gradual formation with obliteration of underlying alveolar structure is apparent. The cells are cuboidal to tall columnar cells with moderate cellular atypia. (B) Pulmonary localized proliferating lesion of a hamster in the $\operatorname{In}_{2} \mathrm{O}_{3} 5.4 \mathrm{mg}$ group at 40 wk. Localized alveolar or bronchiolar cell proliferation with mild to moderate cellular atypia creating focal tubular configuration is evident. Squamous cell metaplasia is apparent. 
localized bronchiolo-alveolar cell hyperplasia also appeared in the ITO $6 \mathrm{mg}$ group and in the $\mathrm{In}_{2} \mathrm{O}_{3} 2.7 \mathrm{mg}$ and $5.4 \mathrm{mg}$ groups. It was characterized by columnar or cuboidal epithelial hyperplasia focally involving the bronchioli or alveoli of the lung (Fig. 5). The incidence rate of localized bronchiolo-alveolar cell hyperplasia manifestation was $20 \%$ in the ITO $6 \mathrm{mg}$ group, $12.5 \%$ in the $\mathrm{In}_{2} \mathrm{O}_{3} 2.7 \mathrm{mg}$ group, $12.5 \%$ in the $\mathrm{In}_{2} \mathrm{O}_{3} 5.4 \mathrm{mg}$ group, but zero in the ITO $3 \mathrm{mg}$ group and the control group.

\section{Discussion}

In this study, the chronic pulmonary toxicity of ITO or $\mathrm{In}_{2} \mathrm{O}_{3}$ particles was demonstrated by their instillation into the lungs of hamsters. This is apparently the first report to evaluate the chronic toxicity of ITO or $\operatorname{In}_{2} \mathrm{O}_{3}$ particles. Previously, we reported the pulmonary toxicity of $6 \mathrm{mg} /$ $\mathrm{kg}$ InP and the same dose of ITO particles by repeated intratracheal instillations to hamsters once a week for 16 wk, and InP demonstrated greater systemic effects than ITO $^{11)}$. In this study, because the instillation period was shortened from 16 to $8 \mathrm{wk}$, with administration twice a week instead of once a week, ITO was administered at the same total dose or half the total dose used in the earlier study ${ }^{11)}$. Since there was no significant difference concerning the trends in body weight gain between the ITO $6 \mathrm{mg}$ group and the control group during the observation period as well as in our previous study ${ }^{11)}$, body weight gain was not influenced by shortening the instillation period.

In this study, although there was no additional exposure to ITO or $\mathrm{In}_{2} \mathrm{O}_{3}$ particles after $8 \mathrm{wk}$ following the initial instillation, significant weight reduction in the late observation period after $40 \mathrm{wk}$ was observed in the ITO
$6 \mathrm{mg}$ group compared with both the ITO $3 \mathrm{mg}$ group and the control group. Relative lung weight increased from week 0 to the end of observation period in all groups, except for the ITO $3 \mathrm{mg}$ group at $78 \mathrm{wk}$, and almost all lung lesions continued to be evident throughout the observation period among the experimental groups. Nevertheless, although the degree of lung lesion manifestation was mostly slight from 0 to $40 \mathrm{wk}$, the toxic effect became worse in the two ITO groups at $78 \mathrm{wk}$. Since ITO and $\mathrm{In}_{2} \mathrm{O}_{3}$ particles are insoluble in water ${ }^{14,15)}$, these findings would seem to be related to the low solubility of ITO and $\mathrm{In}_{2} \mathrm{O}_{3}$ particles within the lung. Since a considerable quantity of ITO or $\mathrm{In}_{2} \mathrm{O}_{3}$ particles was observed within the lung up to the end of the observation period, we suspect that the long-term persistence of ITO or $\mathrm{In}_{2} \mathrm{O}_{3}$ particles within the lung resulted in continuous damage to the alveolar epithelial cells. Despite this, accumulated ITO or $\operatorname{In}_{2} \mathrm{O}_{3}$ particles in the lungs of hamsters dissolved slowly and a dissolved form of indium appeared in the serum, increasing over time. In this study, serum indium levels among ITO- or $\mathrm{In}_{2} \mathrm{O}_{3}$-treated hamsters increased gradually up to the end of the observation period. This finding was inconsistent with the results of Yamazaki et al. ${ }^{9)}$ who reported that the trend of serum indium level among InAs- or InP-treated hamsters decreased gradually until $88 \mathrm{wk}$ following the final instillation. In their study, the mean total dose of InAs particles per animal was $7.89 \pm 0.58 \mathrm{mg}(4.77 \pm$ $0.35 \mathrm{mg}$ as $\mathrm{In}$ ) and that of InP particles per animal was $6.04 \pm 0.40 \mathrm{mg}(4.75 \pm 0.32 \mathrm{mg}$ as $\mathrm{In})$. Furthermore, the serum indium levels among the InAs- or InP-treated hamsters were $7.62 \pm 1.43 \mu \mathrm{M}(876.3 \pm 164.4 \mu \mathrm{g} / l)$ and $3.17 \pm 0.56 \mu \mathrm{M}(364.6 \pm 64.4 \mu \mathrm{g} / l)$ at week 0 after the

Table 2. Lung adenoma or localized alveolar or bronchiolar cell proliferating lesions after $40 \mathrm{wk}$ in the two ITO and the two $\mathrm{In}_{2} \mathrm{O}_{3}$ groups

\begin{tabular}{|c|c|c|c|}
\hline \multirow[t]{2}{*}{ Group } & \multicolumn{2}{|c|}{ Weeks after final instillation (wk) } & \multirow[t]{2}{*}{ Total incidence rate } \\
\hline & 40 & 78 & \\
\hline \multicolumn{4}{|c|}{ Adenomas } \\
\hline ITO $3 \mathrm{mg}$ & $0 / 7$ & $0 / 6$ & $0 \%$ \\
\hline ITO $6 \mathrm{mg}$ & $1 / 8$ & $2 / 7$ & $20.0 \%(3 / 15)$ \\
\hline $\mathrm{In}_{2} \mathrm{O}_{3} 2.7 \mathrm{mg}$ & $0 / 8$ & ND & $0 \%$ \\
\hline $\mathrm{In}_{2} \mathrm{O}_{3} 5.4 \mathrm{mg}$ & $0 / 8$ & ND & $0 \%$ \\
\hline Control & $0 / 7$ & $0 / 6$ & $0 \%$ \\
\hline \multicolumn{4}{|c|}{ Localized alveolar or bronchiolar cell proliferating lesions } \\
\hline ITO $3 \mathrm{mg}$ & $0 / 7$ & $0 / 6$ & $0 \%$ \\
\hline ITO $6 \mathrm{mg}$ & $1 / 8$ & $2 / 7$ & $20.0 \%(3 / 15)$ \\
\hline $\mathrm{In}_{2} \mathrm{O}_{3} 2.7 \mathrm{mg}$ & $1 / 8$ & ND & $12.5 \%(1 / 8)$ \\
\hline $\mathrm{In}_{2} \mathrm{O}_{3} 5.4 \mathrm{mg}$ & $1 / 8$ & ND & $12.5 \%(1 / 8)$ \\
\hline Control & $0 / 7$ & $0 / 6$ & $0 \%$ \\
\hline
\end{tabular}

ND: Not determined. 
final instillation, and the serum indium level in the InAstreated hamsters was about double that in the InP-treated hamsters, even though an equimolar amounts of InAs and InP particles were instilled into the lung. We speculate that the difference in the change of serum indium level between ITO or $\operatorname{In}_{2} \mathrm{O}_{3}$-treated hamsters and InAs or InP-treated hamsters during the observation period is due to differences in particle solubility or clearance in the body. Therefore, it seems that the manner of release of indium from each indium compound is not same in the body. Furthermore, although the degree of lung lesion appearance among the two ITO groups was similar, the trend in body weight change of the ITO $6 \mathrm{mg}$ group from 40 to $78 \mathrm{wk}$ was significantly below that of the ITO $3 \mathrm{mg}$ group. The serum indium level at $78 \mathrm{wk}$, which was higher in the ITO $6 \mathrm{mg}$ group than the ITO 3 $\mathrm{mg}$ group, may correlate with the disparity in body weight reduction. Moreover, since the serum indium levels and the degree of lung lesions among ITO- or $\mathrm{In}_{2} \mathrm{O}_{3}$-treated hamsters were almost the same up to $40 \mathrm{wk}$ following the final instillation, it seems that the toxic potency of the particles is almost same at the dosage levels used in this study. On the other hand, although pulmonary fibrosis caused by inhaled ITO particles has developed in the human cases, the degree of interstitial fibrotic proliferation was slight during the observation period among ITO- or $\operatorname{In}_{2} \mathrm{O}_{3}$-treated hamsters in this study. The differences in fibrosis manifestations between humans and hamsters are not clear, but they may arise from the instillation method, the deposited dose of particles in the lungs or species differences between humans and hamsters. Further clarification is necessary regarding indium deposition in the lung to confirm the pulmonary clearance of indium compound particles.

National Toxicology Program (NTP $)^{8)}$ and Gottschling et $a l .{ }^{10)}$ reported that benign and malignant lung tumors were caused when rats and mice were exposed to InP particles. The incidence rates of benign and malignant tumors in the InP-treated animals increased significantly compared to that in the control group. Furthermore, these studies mention that there were non-neoplastic lesions, accompanying extensive, severe inflammatory lesions, in addition to lung tumor development, and also that oxidative stress played a major role in the development of lung tumors induced by InP exposure. Although carcinogenic evidence of InP has been adequately demonstrated in animals, it has been inadequately studied in humans. As a result of the above studies, InP was evaluated as probably carcinogenic to humans (Group 2A) by the International Agency for Research on Cancer ${ }^{16)}$. However, based on the evidence of the carcinogenicity of InP, it would seem that indium compounds probably induce neoplastic changes. In the current study, there was no significant increase in benign lung tumor incidence following intratracheal instillation in either of the two ITO groups or the two $\mathrm{In}_{2} \mathrm{O}_{3}$ groups compared with the control; benign lung tumors were only manifested in the ITO $6 \mathrm{mg}$ group, and their incidence was not significant. Furthermore, localized alveolar or bronchiolar cell proliferating lesions were observed in all the experimental groups, except for the ITO $3 \mathrm{mg}$ group. This finding was consistent with the results of our previous studies $2,4,7,9,11,12$, in which InAs or InP was administered to the trachea of hamsters. As for the observation period of the two $\operatorname{In}_{2} \mathrm{O}_{3}$ groups, it was shorter than that of the two ITO groups (40 wk vs 78 wk after the final instillation). This was because, at first, we thought that an observation period of $40 \mathrm{wk}$ would be enough for observing hamsters in the $\mathrm{In}_{2} \mathrm{O}_{3}$ group, and we accordingly set an observation period of $78 \mathrm{wk}$ only for hamsters in the ITO group. Additional animal studies, focusing on long-term observation are required to confirm whether the localized alveolar or bronchiolar cell proliferating lesions brought about by $\mathrm{In}_{2} \mathrm{O}_{3}$ treatment represent neoplastic change or not. The toxicity of inorganic tin, including tin oxide, after inhalation and ingestion is low ${ }^{17}$. Since ITO contains a high ratio of indium, but very little tin, the main cause of the lung lesions is clearly not the tin, but is rather the indium. In addition, although it is not clear whether it is the ITO or $\mathrm{In}_{2} \mathrm{O}_{3}$ particles, or simply the indium dissolved from these particles that contributes to the development of the pulmonary lesions or benign tumors, indium definitely seems to be main cause of the lung lesions.

To date, 6 cases of lung disorder, mainly interstitial pneumonia, caused by inhaled ITO have been published. Following the first case report involving death ${ }^{13)}$, a second case of lung disease related to inhaled ITO was reported in $2005^{18)}$. A worker developed pulmonary fibrosis and emphysema after a 4-yr occupational exposure to ITO. His serum indium level was $51 \mu \mathrm{g} / \mathrm{l}$, and he showed no progression of the pulmonary disease. Taguchi et al. ${ }^{19)}$ reported a further 3 cases of interstitial pulmonary disease related to ITO-grinding work. These 3 cases showed a high serum indium level, high sialylated carbohydrate antigen Krebs von den Lungen-6 (KL-6) (standard level $<500 \mathrm{U} / \mathrm{ml}$ ), and interstitial change in the lung or pneumothorax on high-resolution computed tomography (HRCT). Nakano et al. ${ }^{20)}$ reported the case of a man, who was engaged in the process of ITO handling who was detected following a health examination for the effects of indium. The worker showed a high serum indium level and KL-6, interstitial changes in the lung on HRCT and cholesterol clefts were observed in a pathological examination. Regarding the epidemiological study of indium compounds, Chonan et al. ${ }^{21)}$ reported interstitial pulmonary disorders in indium-processing workers. Their study was performed on 108 males working in an indium plant. Twenty-three workers showed interstitial changes in the lung on HRCT and 40 
workers showed an increased level of serum KL-6. The serum indium level among the workers was related to the KL-6 level and also to the degree of HRCT change. Furthermore, Hamaguchi et al. ${ }^{22)}$ reported that indium compounds caused interstitial lung damage in indiumexposed workers. Elevated serum indium concentration, and a higher level of KL-6, SP-D or SP-A among 93 workers exposed to indium were observed when compared with those in 93 workers with no such exposure. In the current study, the lung lesions observed in the two ITO and the two $\mathrm{In}_{2} \mathrm{O}_{3}$ groups were mostly similar, except for lung adenomas in the ITO $6 \mathrm{mg}$ group and granulomas in the $\mathrm{In}_{2} \mathrm{O}_{3}$ groups. Furthermore, the pulmonary lesions, especially cholesterol clefts, expansion of alveolar spaces, and interstitial fibrotic proliferation, observed in the current study were consistent with both the findings of case reports and the results of epidemiological studies among workers handling ITO.

In conclusion, the chronic pulmonary toxicity of ITO and $\mathrm{In}_{2} \mathrm{O}_{3}$ particles was confirmed by repeated intratracheal instillations administered to hamsters, and the possibility that ITO has neoplastic activity was suggested. It is thus essential to pay much greater attention to the danger of human exposure to indium compounds.

Acknowledgments: This study was funded in part by a Grant-in-Aid for Scientific Research (B) (19390164) from the Ministry of Education, Culture, Sports, Science and Technology of Japan. The English used in this manuscript was revised by Miss K. Miller (Royal English Language Centre, Fukuoka, Japan).

\section{References}

1) Arumu Publishing Co. Indium. In: Industrial rare metals, No. 124. Tokyo: Arumu Publishing Co; 2008. p.114-5 (in Japanese).

2) Tanaka A, Hisanaga A, Hirata M, Omura M, Inoue N, Ishinishi N. Pulmonary toxicity of indium arsenide and arsenic selenide following repeated intratracheal instillations to the lungs of hamsters. Appl Organomet Chem 1994; 8: 265-71.

3) Zheng W, Winter SM, Kattnig MJ, et al. Tissue distribution and elimination of indium in male Fischer 344 rats following oral and intratracheal administration of indium phosphide. J Toxicol Environ Health 1994; 43: 483-94.

4) Tanaka A, Hisanaga A, Hirata M, et al. Chronic toxicity of indium arsenide and indium phosphide to the lung of hamsters. Fukuoka Acta Medica 1996; 87: 108-15.

5) Oda K. Toxicity of a low level of indium phosphide $(\mathrm{InP})$ in rats after intratracheal instillation. Ind Health 1997; 35: 61-68.

6) Uemura T, Oda K, Omae K, et al. Effects of intratracheally administered indium phosphide on male Fischer 344 rats. J Occup Health 1997; 39: 205-10.

7) Tanaka A, Hirata M, Omura M, et al. Comparative study of the toxic effects of gallium arsenide, indium arsenide and arsenic trioxide following intratracheal instillations to the lung of Syrian golden hamsters. Fukuoka Acta Medica 2000; 91: 21-33.

8) National Toxicology Program (NTP). Toxicology and carcinogenesis studies of indium phosphide (CAS No. 22398-80-7) in $\mathrm{F} 344 / \mathrm{N}$ rats and $\mathrm{B} 6 \mathrm{C} 3 \mathrm{~F} 1$ mice (inhalation studies), NTP TR 499. Research Triangle Park (NC): U.S. Department of Health and Human Services, Public Health Service, National Institute of Health; 2001. p.1-348.

9) Yamazaki K, Tanaka A, Hirata M, et al. Long term pulmonary toxicity of indium arsenide and indium phosphide instilled intratracheally in hamsters. J Occup Health 2000; 42: 169-78.

10) Gottschling BC, Maranpot RR, Hailey JR, et al. A. The role of oxidative stress in indium phosphideinduced lung carcinogenesis in rats. Toxicol Sciences 2001; 64: 28-40.

11) Tanaka A, Hirata M, Omura M, et al. Pulmonary toxicity of indium-tin oxide and indium phosphide after intratracheal instillations into the lung of hamsters. J Occup Health 2002; 44: 99-102.

12) Tanaka A, Hirata M, Omura M. Pulmonary squamous cyst induced by exposure to indium arsenide in hamsters. J Occup Health 2003; 45: 405-7.

13) Homma T, Ueno T, Sekizawa K, Tanaka A, Hirata M. Interstitial pneumonia developed in a worker dealing with particles containing indium-tin oxide. J Occup Health 2003; 45: 137-39.

14) Swarts S. Material safety data sheet (MSDS): Indium tin oxide. MSDS No. MSDS-IB011. [Online]. 2006 [cited 2008 August 19]; Available from: URL:http:// www/indium.com/documents/msds/IB011.

15) Merk \& Co., Inc. Indium Oxide. In: Budavari S, editor. The Merk Index, 12th ed. Whitehouse Station (NJ): Merk \& Co., Inc.; 1996. p.850-1.

16) IARC. Cobalt in hard metals and cobalt sulfate, gallium arsenide, indium phosphide and vanadium pentoxide. IARC Monographs on the Evaluation of Carcinognic Risks to Humans Vol. 86. Lyon: IARC; 2006. p.197224.

17) Mogos L. Tin. In: Friberg L, Nordberg GF, Voul VB, editors. Handbook on the Toxicology of Metals. Vol. II: Specific metals. Amsterdam: Elsevier; 1986. p. 568-93.

18) Homma S, Miyamoto A, Sakamoto S, Kishi K, Motoi $\mathrm{N}$, Yoshimura K. Pulmonary fibrosis in an individual occupationally exposed to inhaled indium-tin oxide. Er Respir J 2005; 25: 200-4.

19) Taguchi O, Chonan T. Three cases of indium lung. J Jpn Respir Soc 2006; 44: 532-35 (in Japanese).

20) Nakano M, Kamata H, Saito F, et al. A case of indium lung diagnosed by workers' health examination. Occup Health J 2007; 30: 25-9 (in Japanese).

21) Chonan T, Taguchi O, Omae K. Interstitial pulmonary disorders in indium-processing workers. Eur Respir J 2007; 29: 317- 24.

22) Hamaguchi T, Omae M, Takebayashi $T$, et al. Exposure to hardly soluble indium compounds in ITO production and recycling plants is a new risk for interstitial lung damage. Occup Environ Med 2008; 65: 51-5. 